\title{
The making of a 'superstar': the politics of playback and live performance in post-genocide Rwanda
}

\author{
Andrea Mariko Grant
}

After months of events and roadshows around the country, the ten hopeful contestants of Rwanda's Primus Guma Guma Super Star Season 2 competition returned to Kigali in June 2012 for a final round of performances. Unlike the roadshows, which had involved 'playback' - singers and rappers had lip-synced along to recorded tracks - the performances at the Gikondo Expo Grounds would be 'live' and broadcast on RTV, the state-controlled television channel. After the performances, Rwandans from Cyangugu to Kibungo would have the chance to vote online or through SMS to determine the country's second ever 'superstar'. Up for grabs was a prize package worth 24 million Rwandan francs (roughly £24,000), an extraordinary sum in the country's nascent post-genocide music industry.

On 23 June 2012, a sizeable crowd of entertainment journalists, musicians, radio presenters, promoters and lucky fans gathered at the Expo Grounds for the first 'live' televised performance. On the bill were R\&B singers King James and Knowles; boy bands Urban Boys, Dream Boys and Just Family; and rappers Jay Polly, Riderman, Bulldogg, Dany Nanone and Young Grace. With a few exceptions, all were established performers. Unlike Western 'reality' music competitions such as X Factor or American Idol, Guma Guma pitted Rwanda's most popular artists against each other. This was not a competition for amateurs.

As performer after performer took to the stage, however, elaborately choreographed dance routines and immaculately styled outfits could not make up for the disappointment that slowly seeped into the crowd. While the rappers had confidently performed their flows accompanied by the live band, the R\&B crooners and boy bands had not fared so well. As singers belted out their hits with offkey abandon, audience members around me cringed. To many in the crowd, Guma Guma 2 confirmed what they had long suspected: the vast majority of the country's 'stars' had been lying to them. They didn't know how to sing and had manipulated the public's goodwill in achieving fame and (relative) fortune.

\section{Introduction}

This article considers technological mediation and the ways in which changes in recording technology not only shape performance and audience reception, but may provide vocabularies for considering relations of power more broadly. I explore local ideas about 'playback' and 'live' during the second season of the wildly successful Rwandan music competition, Primus Guma Guma Super Star,

\footnotetext{
Andrea Mariko Grant is a Research Fellow at Emmanuel College and the Centre of African Studies at the University of Cambridge. Her work explores religion and popular culture in contemporary Rwanda, in particular the rise of the new born-again churches and the reconstruction of the music industry after the genocide. Email: amg68@cam.ac.uk
} 
and argue that these two performative categories can be understood as wider metaphors for the relationship between the Rwandan state and its citizens, particularly Rwandan youth. I contribute not only to the wider field of scholarship on popular culture in Africa (Askew 2002a; Barber 1997; Fabian 1998; McNeill 2011; Schumann 2012; 2013; Shipley 2013; Weiss 2009), but more specifically to studies that take mediation as their point of departure (Larkin 2004; Meintjes 2003; Pype 2012). What interests me are the ways in which specific technologies of mediation are understood to have become politicized in particular sociopolitical contexts (Mazzarella 2004), and how the category of 'liveness' becomes intertwined with discourses of authenticity and 'truth'. I ask: how can audience demands for 'live' be seen as a way to contest power - that is, as a way to call attention to the fact that playback is constituted in its relationship to the live, and that the live may open up possibilities for alternative kinds of practices and relations (with the state and with others)? How might 'liveness' itself become a form of mediation?

My analysis proceeds as follows. I consider how Guma Guma's attempts to create a new kind of Rwandan celebrity - what I call a post-genocide celebrity subject - were caught up in the wider nation-building project of the ruling Rwandan Patriotic Front (RPF), particularly through the construction of an inclusive, de-ethnicized Rwandan or banyarwanda identity. As critics allege, the RPF's post-genocide governance is defined by authoritarianism, with little room for political opposition or freedom of speech (Reyntjens 2013; Straus and Waldorf 2011; Thomson 2013). In such a political climate, I argue that playback performances are central to the RPF's nation building. By attending genocide memorials and declaring their commitment to help rebuild (kubaka) the nation, Guma Guma contestants were required to 'play back' a unified banyarwanda identity to the state and to Rwandan audiences both at home and abroad. Following Wedeen (1999), I suggest that these playback performances cultivated compliance, as contestants were required to act and speak 'as if' they believed in the post-genocide claims of the state, regardless of whether they did so in their everyday lives. Although popular culture has been considered a space of the 'unofficial' (Barber 1987; Fabian 1998), material from Rwanda challenges this in two respects: not only are popular artists required to perform for the state, but seemingly 'private' companies that sponsor musical events are intimately tied to the RPF (Gökgür 2012).

Rwandan audiences, however, did not passively accept these playback performances. Guma Guma generated heated debate about supposedly 'taboo' topics, revealing enduring differences along socio-economic, ethnic and regional lines. Rather than affirm an inclusive banyarwanda identity, these 'live' surprises hinted at its fragility and underscored the multiple and conflicting ways in which young people identify themselves and remember the past in the post-genocide era. More importantly, Guma Guma also provoked audience demands for 'live' performance. In local vocabularies, 'live' was often synonymous with 'truth', and the 'truth' demanded was complex and shifting. ${ }^{1}$ On the one hand, singers'

\footnotetext{
${ }^{1}$ As I go on to discuss in more detail below, although the English word 'live' was used to describe non-playback musical performance, the term 'live music' was also translated into Kinyarwanda as 'umuziki w'ukuri' - literally, 'the music of truth'.
} 
inability to perform live suggested their failure to master the 'right' kind of sound necessary to access global musical markets (Larkin 2004; Meintjes 2003). On the other, 'live' revealed anxieties about the status of 'truth' in the post-genocide era and the lack of transparency in public life (Fujii 2010; Ingelaere 2009; Reyntjens 2015). Playback and live performance ultimately revealed the ambiguity at the heart of the RPF's banyarwanda project, and suggested that 'liveness' might offer a site of political potentiality, even if demands for live performance were never made on political actors.

Although scholars have quite rightly attempted to dissolve the boundary between the live and the mediated (Auslander 1999; Porcello 2002), I suggest that the boundary continues to do political work. The categories of playback and live are particularly salient in the Rwandan context because the government views technological advancement as central to its Vision 2020 development programme. ${ }^{2}$ As social reality becomes increasingly technologized or mediatized if only for some - then 'live' might offer alternative ways of relating for ordinary citizens, and may call attention to the 'gaps' (Larkin 2004: 305) that technology creates between those who can access it and those who cannot. Given that other developmental states in Africa and elsewhere focus on technology as a benchmark of development, the category of 'live' might remain analytically useful in other contexts.

This article is based on sixteen months of fieldwork on popular culture in Kigali, between 2011 and 2013. I conducted more than seventy formal and informal interviews with musicians, promoters, producers, entertainment journalists, fans and DJs. Although I also conducted interviews in more rural areas, the viewpoints here are mostly of lower- to middle-class youth who live and work (mostly intermittently) in the capital, particularly in the 'ghetto' of Nyamirambo. They represent a variety of ethnic backgrounds and experiences. ${ }^{3}$ Similarly, although during the course of my fieldwork I interviewed a mix of younger and older musicians, my interest here lies mostly in the viewpoints of the 'new' generation of musicians and music fans who began developing the local music industry in the mid-2000s. I also draw on my experiences following the second season of Guma Guma - I attended a number of its events, roadshows and 'live' performances and interviews with the competition's organizers. Finally, I consider the substantial local media coverage of Guma Guma, in both English and Kinyarwanda.

\section{Rwanda's musical history: a brief sketch}

Before turning to the Guma Guma competition, it is necessary to first briefly sketch out Rwanda's musical history. As has been well documented, during the

\footnotetext{
${ }^{2}$ The government's Vision 2020 programme, which aims to transform Rwanda into a middleincome economy by 2020, cites science, technology and ICT as central to the country's development. To this end, a 'Smart Kigali' initiative was launched in 2013 that aims to provide free Wi-Fi in public spaces and on public transport, in addition to improving internet connectivity across the city.

${ }^{3}$ Some had been born and raised in Rwanda, members of the so-called abasope, which I discuss below, and others had returned to Rwanda after the genocide from countries such as Burundi, Uganda, Kenya and the Democratic Republic of the Congo (DRC).
} 
1994 genocide, which claimed the lives of roughly 1 million Tutsi and moderate Hutu, the country's so-called 'hate media' played a lethal role (Chrétien 1995; Straus 2012; Thompson 2007; Vokes 2007). The notorious Radio-Télévision Libre des Mille Collines (RTLM), which broadcast between July 1993 and October 1994, acted as a catalyst for violence. Not only did RTLM's vitriolic anti-Tutsi - and anti-moderate Hutu - propaganda exacerbate ethnic tensions prior to April 1994, it actively encouraged citizens to participate in the genocide, in some cases identifying specific individuals to be slaughtered and later congratulating the killers on air (Des Forges 2007: 49; Prunier 1995: 189). In the famed 'media' judgment handed out at the International Criminal Tribunal for Rwanda (ICTR) in 2003, three journalists - two radio, one print - were found guilty of inciting genocide and crimes against humanity, among other charges. ${ }^{4}$

Popular musicians participated in this propaganda. One artist whose music was regularly played on RTLM was Simon Bikindi. Bikindi's songs - notably 'Nanga abahutu' ('I hate these Hutu'), 'Twasezereye' ('We said goodbye to the feudal regime') and 'Bene Sebahinzi' ('Sons of the cultivators') - have since been accused of inciting genocide. In 2008, Bikindi was convicted by the ICTR of 'direct and public incitement to commit genocide' and sentenced to fifteen years in prison.

Yet it is important to point out that despite the prevalence of this narrative that 'hate radio' and extremist songs directly caused violence during $1994-$ recent scholarship has called for a more nuanced view. Straus (2012) has suggested that we should be wary of overstating the effects of 'Radio Machete'. He argues that, while radio did have 'conditional' effects, it 'could not account for either the onset of most Rwandan genocidal violence or the participation of most perpetrators' (Straus 2012: 85). In a similar vein, McCoy has pushed for a re-reading of Bikindi's legacy, arguing that Bikindi's songs 'never explicitly called for violence against Tutsi nor denigrated them in any obvious way' (McCoy 2013: 9; see also Craig and Mkhize 2006). Many of his songs had been composed and released prior to the genocide. ${ }^{5}$ It is also worth noting that Bikindi was convicted at the ICTR not because of his songs but because of 'pro-genocide statements' he was said to have made near Gisenyi (McCoy 2013: 11). ${ }^{6}$

Furthermore, a focus on RTLM and Bikindi occludes a much more complicated musical landscape that stretches back to the precolonial era. Throughout Rwanda's history, music, dance and oral art forms often reinforced structures of inequality and power (Coupez and Kamanzi 1962; Kagame 1951; for a more recent discussion, see Barber 2007). Under the Nyiginya kingdom (1650-1897), for example, a wide variety of oral art forms were developed to create a 'royal

\footnotetext{
${ }^{4}$ These were Ferdinand Nahimana, 'founder and ideologist' of RTLM; Jean-Bosco Barayagwiza, a prominent board member of RTLM and founding member of the extremist political party Coalition for the Defence of the Republic (CDR); and Hassan Ngeze, chief editor of the extremist newspaper Kangura (UNMICT 2003). Nahimana and Ngeze received life sentences, while Barayagwiza was sentenced to thirty-five years in prison.

5'Twasezereye', for example, was released in 1987 but began recirculating in 1992-93 as 'an anthem for Hutus dissatisfied with the strictures of the Arusha Accords' (Craig and Mkhize 2006: 42).

${ }^{6}$ The trial's judges justified Bikindi's conviction by claiming that his celebrity meant that 'he wielded enough influence to incite genocide through means of speech' (McCoy 2013: 11).
} 
ideology' (Vansina 2004: 4) that legitimized the authority of the king (mwami) and the Tutsi elite. Barber (2007) has argued that genres such as ibisigo (dynastic poetry) were 'bearers of social relations', as their complexity required specialist knowledge to decipher - knowledge that only the Tutsi elite had the time and ability to cultivate. At the same time, popular art forms, associated with Hutu, circulated on the hillsides and varied greatly based on region. In terms of dance, for example, although imihamirizo (a warrior dance) was performed by intore, young Tutsi men of noble birth during itorero, military and cultural training camps, dances such as ikinimba (an energetic Hutu dance) were popular in the north (Plancke 2015: 716-17; Nkulikiyinka 2002).

In the post-independence period, music and art forms became the staging grounds for divisive ethnic politics. After the so-called Hutu Revolution (1959-62), in which Tutsi privilege was overturned in favour of the Hutu majority, Tutsi art forms, particularly those associated with the royal court, were more or less banned. By the time ethnomusicologist Gansemans began conducting research in the 1970s, not only had a significant portion of Tutsi musical culture disappeared, but what endured had been heavily modified (1988: 28). Under the Habyarimana regime (1973-94), music and dance were used as forms of political mobilization. State employees and even those working in the private sector were required to participate in weekly 'animation' sessions during which they would sing or chant 'litanies about the country's development, [and] the accomplishments and qualities of President Habyarimana' and the ruling party, the Mouvement républicain national pour la démocratie et le développement (MRND) (Taylor 1999: 107).

Music, however, was never completely controlled by the government. Firstly, from the 1970s onwards, there was a vibrant popular music scene. Music groups called orchestres developed a particular style of Rwandese rhumba that addressed the themes of love, relationships and everyday life. While one of the most popular groups from this period was Impala, an orchestre sponsored by the MRND, not every group or artist was intimately associated with the state. Some popular musicians veiled political critique in their songs. One of the most important of these figures was Cyprien Rugamba, a well-respected Hutu artist, choreographer, composer and cultural figure who developed a unique musical style that drew on Gregorian chant, reflecting his Catholic faith. Through allegory and allusion, many of his songs - particularly 'Agaca' ('The falcon') - were indirect critiques of the increasingly violent and corrupt Habyarimana regime. After the genocide, this pre-genocide music was referred to as igisope, as it was said to be beloved by abasope - Rwandans, both Tutsi and Hutu, who had been born and raised in the country. ${ }^{7}$

Secondly, music was an important form of political motivation in the diaspora, especially once the RPF launched its Liberation War from Uganda in $1990 .{ }^{8}$ Tutsi

\footnotetext{
${ }^{7}$ Abasope is the shortened version of abasopecya, which derives from SOPECYA (Société Pétrolière de Cyangugu), allegedly the only petrol station in the country to stay open during the genocide. Thus, after 1994, Rwandans who had been born in the country and had survived the genocide were colloquially known as the abasope - literally, the people of SOPECYA.

${ }^{8}$ It is also worth pointing out that traditional dance groups were another important way in which Tutsi culture was kept alive in the diaspora (Plancke 2013; 2015: 717-18).
} 
artists such as Cécile Kayirebwa, Jean-Paul Samputu, Masamba Intore and Maria Yohana Mukankuranga all performed songs in the late 1980s and early 1990s to raise money for the RPF's Liberation War and to inspire young people to join the RPA (the Rwanda Patriotic Army) (Kagire 2015; see also Swanson 2014). This is not to imply that these artists shared the same musical or personal histories. Samputu, for example, had been a member of popular igisope groups Nyampinga and Ingeli, and fled into exile only after the RPF invasion. Kayirebwa, on the other hand, had left Rwanda for Belgium in 1973, and given that her songs were used on the RPF's radio station, Radio Muhabura, her music was more closely aligned with the Liberation Struggle. ${ }^{9}$

\section{Starting from zero: rebuilding the music industry after the genocide}

The genocide, however, more or less destroyed the local music industry. ${ }^{10}$ Not only were popular artists killed - Rugamba, for example, and André Sebanani, the Tutsi frontman of Impala - many others were eventually jailed for their participation in the violence or fled into exile. Young artists stressed the musical and cultural rupture the genocide entailed, telling me that when they began singing in the mid-2000s, they felt as though they were starting the music industry 'from scratch' or 'from zero'. As Miss Jojo, a pioneering female singer of the 'new' generation, told me:

Before the genocide, there wasn't really a strong musical culture. There were some groups, some orchestres that could do shows here and there, but ... it wasn't something that people really appreciated or gave value to. When we began, it was like breaking out of nowhere, we were putting the foundation, if I can say.

Despite such statements, there had been earlier efforts by older artists to re-establish the local music industry. After the genocide, Samputu returned to Rwanda and opened a studio, where he recorded a number of his own songs and albums in addition to making jingles for breweries and non-governmental organizations (NGOs) (Swanson 2014: 109). Samputu eventually left Rwanda for Canada; while there, he recorded an album, Igihe Kirageza (The Time Has Come), in 1999 with famed Rwandan producer Aron Nitunga (Swanson 2014: 110-11). The album, particularly the songs 'Nyaruguru' and 'Nimuze Tubyine', were played on Radio Rwanda and became hits (Swanson 2014: 111). At the time, Radio Rwanda played a mixture of regional and international pop songs, local choral or religious music, and songs by diasporic singers. Any songs associated with the old regime or written by artists deemed 'génocidaires' were banned.

\footnotetext{
${ }^{9}$ Not only did one of Kayirebwa's songs open and close Radio Muhabura broadcasts, but other songs such as 'Intsinzi' ('Victory') and 'Inkindi' ('A strong and proud fighter'), which celebrate the 'sacrifices and successes' of the RPF, were later used in the film about the genocide, 100 Days (Dauge-Roth 2010: 208).

${ }^{10}$ The Association of Rwandan Musicians (LIRAM) has compiled a list of fourteen artists who were killed, but this includes only famous artists and not those who were less well known (Kagire 2013).
} 
Additionally, in the mid-1990s and early 2000s, there was a small local music scene. John Safari Papy (or Safa Papy), a singer and keyboardist from this period, told me that he had helped open the first 'rock cafe'' at the Piano Bar in downtown Kigali in 1995. For two years, he said, it was the only place to hear live music. He played American pop songs and reggae songs, and other artists performed Congolese music, rock and blues. The audience was a mixture of abasope, returnees and expatriate NGO workers. Other notable musicians from this period were Natty Dread, a Rwandan reggae artist who had been born in Uganda, and Ben Rutabana, a Rwandan singer from Kibuye who had been an RPF soldier. The pair performed concerts together around the country in venues ranging from football stadiums to large hotels. There were also several bands made up of Rwandan, other African and European musicians that regularly played in nightclubs (Cadillac, Mango and Turtle Café, among others) in Kigali and occasionally across the country. A member of one of these groups was Albert Rudatsimburwa, a Rwandan-Belgian dual citizen who later founded one of the first post-genocide independent radio stations, Contact FM. ${ }^{11}$

Among the young people I spoke to, however, these earlier initiatives were rarely referenced. Instead, they told me that the 'modern' music industry had started through dance. In the late 1990s and early 2000s, young men and women began to form dance groups that performed choreographed dance routines to foreign pop songs. Adolphe Bagabo (aka Kamichi), a popular Afrobeat singer, had been a member of a dance group called Hot Side. Although he had begun singing in the Adventist Church, he became a dancer in 2002. He explained his interest in dance to me in this way:

I went to [join] a dancing club 'cos singing died with the genocide. We didn't have new artists since 1994. No studios, all the artists died ... So everybody was a dancer. I used to go to the TV, watch NSync, then copy their choreography and take it to my friends. Then I was Justin Timberlake! We would dance, and people would enter for 100 or 200 [Rwandan] francs.

These dance groups became popular among young people in Kigali, and were often formed based on neighbourhood.

While we might understand young artists' failure to mention earlier artists as a way to foreground their own contributions, we might also see the elision of certain artists - particularly Rutabana - as a form of 'chosen amnesia' (Buckley-Zistel 2006), or what I have elsewhere termed 'pretending to forget' (Grant 2015: 26-7). Despite having been a soldier with the RPF from 1990 to 1995 and composing pro-RPF songs, Rutabana was jailed in 2000 (Burnet 2012: 119-20). He was accused of supporting a monarchist opposition group known as ingabo z'umwami (army of the king), which was rumoured to be organizing in Uganda (Burnet 2012: 119-21). Rutabana was reportedly released only after he agreed 'to sing his pro-RPF songs, to do a national tour sponsored by MTN Rwandacell $\ldots$ and to avoid associating with opposition members' (Burnet 2012: 121). Rutabana fled into exile in Europe in 2004. As Buckley-Zistel

\footnotetext{
${ }^{11}$ Jean Mutsar, a well-respected bassist and the brother-in-law of President Kagame, was also involved in reanimating the music scene.
} 
(2006) has argued, Rwandans often choose to forget particularly sensitive memories of the past - what she terms 'chosen amnesia' - as a way to cope with the present. We might see young artists' forgetting of Rutabana in this light, and as an attempt to distance themselves from a known 'dissenter'.

Like elsewhere on the continent, the turning point of the post-genocide music industry came with the opening of Rwanda's airwaves to privatization in 2002. Given Rwanda's media history, the same law also called for the creation of an independent body to 'deal with' the press, the High Council of the Press (HCP) (Frère 2009: 343). (The HCP was later renamed the Media High Council (MHC) in 2009.) Between 2004 and 2006, more than twenty private radio stations were given broadcasting licences (Frère 2009: 344). The need to fill airtime with local content led to a proliferation of small recording studios, and many young Rwandans began composing and recording R\&B, Afropop, and later hip-hop and rap songs in Kinyarwanda. Artists such as Miss Jojo, Rafiki, Meddy, The Ben, Kigali Boys (KGB) and The Brothers became some of the country's first musical 'stars'. They mostly performed at government-sponsored events and, much like earlier igisope artists, sang about love, relationships and everyday life. Indeed, apart from participating in genocide commemoration songs, these early artists steered clear of directly addressing politics in their songs.

The introduction of the Guma Guma competition in 2011 changed the game. Although companies such as MTN had sponsored various concerts before 2011, Guma Guma upped the ante and turned popular music into a national, months-long, multimedia event. Rwanda's three major telecommunications companies - MTN, Tigo and Airtel - all began using popular artists as their brand ambassadors. Suddenly, the faces and voices of popular artists seemed to be everywhere - on television screens and billboards, but most importantly on the radio, the country's most dominant medium - and entered into the everyday lives of young people across the country.

\section{Guma Guma 1 and 2}

The first Guma Guma took place in 2011. Joseph Mushyoma, head of the promotion company East African Promoters (EAP), which was in charge of running Guma Guma, told me that he had come up with the concept in 2009. 'I was looking how I can help our industry to grow up,' he said. Knowing that the budget required for the project would be substantial, he approached Bralirwa, the largest brewery and soft drink manufacturer in the country and part of the Heineken Group. They agreed, and in May 2011 the first Guma Guma was officially launched. Ten potential 'superstars' were selected by entertainment journalists and industry insiders. Contestants were competing not only for US\$10,000 but also for the opportunity to perform with Jamaican-American recording artist Sean Kingston, known for his international hit single 'Beautiful girls', at a final concert at Kigali's Amahoro stadium. Included in the prize package was a trip to the US to record a song with Kingston and film an accompanying music video. For the months of May and June, contestants performed 'playback' roadshows across the country. Since the shows were free, they attracted tens of thousands of young people, many of whom walked miles from nearby villages to 
attend. In July, the contestants performed live on RTV and, in a series of elimination rounds, the public voted for the winner by SMS. The first winner of Guma Guma was R\&B singer Tom Close, although his win, as I discuss in more detail below, was highly controversial.

Guma Guma 2 followed the same general format as the inaugural season, but with some notable modifications. For one, the prize package now amounted to 24 million Rwandan francs. This time around the featured foreign artist was American R\&B singer Jason Derulo, who, although he had built an audience for himself through the song 'Whatcha say', was not at the time as well known as Kingston. More importantly, however, the Guma Guma experience was now four months long and involved not only roadshows and 'live' televised performances but a number of community activities. Contestants participated in umuganda, community service mandatory for all Rwandans on the last Saturday of every month. They also visited an orphanage, a school for disabled students, and genocide memorials. When I asked Mushyoma why the community outreach activities had been included in the second season, he responded: 'The idea came because you know I'm Rwandese, and we have the history. Even if you do these kinds of events, our artists should know what is happening, they should be involved in government programmes.' During the grand finale on 28 July 2012, $\mathrm{R} \& \mathrm{~B}$ singer King James was crowned the second Guma Guma winner.

By all accounts, Guma Guma was an overwhelming success. For one, it allowed Bralirwa to rebrand Primus, transforming it from the beer of the poor (Sommers 2012: 32) to the beer of the famous. In the first half of 2012, Bralirwa Ltd saw its net profits increase by 45.3 per cent. ${ }^{12}$

Yet, we could ask: if Guma Guma was explicitly about making a new kind of Rwandan 'superstar', what kind of celebrity did it stage and create? How did audiences evaluate claims to 'superstardom'?

\section{The making of a post-genocide celebrity subject}

Despite the growth of work on popular culture in Africa, relatively little has been written about various forms of African celebrity (for exceptions, see Pype 2009; Shipley 2013; Tomás 2014). In the Euro-American context, celebrity has traditionally been understood in terms of manufacture (the star as a "manufactured product of capitalism') or exceptionality (a star possesses a special gift) (Holmes 2004: 155; drawing on Dyer 1998). Writing about the UK show Pop Idol, Holmes has argued that the programme's contestants 'balanc[e] elements of both' (ibid.: 155), but what is most important for success is 'an authentic articulation of the self' (ibid.: 159). This becomes doubly true since Pop Idol, and other music reality TV shows, feature amateur performers largely unknown to the audience (Coutas 2006; Meizel 2011; Punathambekar 2011).

Rwanda's history and current authoritarian governance require a different analytical approach. To begin with, the Guma Guma performers were not unknown amateurs. One of the selection criteria for Guma Guma contestants was that they

\footnotetext{
${ }^{12}$ See $<$ http://www.bralirwa.com/cms/index.php/press-releases $>$.
} 
have 'music hits' under their belt. Rwandan audiences - and Rwandan authorities - were already familiar with the music and public personas of the contestants, and many of them had already composed songs for the state. Tom Close, the winner of the first Guma Guma, had composed 'Tora Kagame Paul' ('Vote for Paul Kagame'), a song for Kagame's 2010 presidential campaign. Fellow Guma Guma contestant King James had helped produce the song.

Within Guma Guma logic, then, a 'superstar' was not an ordinary individual striving to 'authentically' represent him- or herself, but rather a known entity who, through embodied acts and public utterances, was required to perform for the state. I suggest that we consider these acts and utterances as 'playback' to highlight their performative nature and the fact that they aimed to create a specific kind of embodied post-genocide celebrity subject - one who reproduced an inclusive, pan-ethnic banyarwanda identity. ${ }^{13}$ This chimes with other research on arts in the country. Breed, for example, argues that, although grass-roots theatre can offer possibilities for reconciliation, government-sanctioned theatre acts as a 'tool for nation building' (2008: 33) that reinforces a 'singular statedriven narrative' (ibid.: 47; 2014). Similarly, in her work on the resurgence of traditional dance groups in the country, Plancke (2015) argues that groups such as Inganzo Ngari are successful because they embody the post-genocide ideology of a 'New Rwanda'. By performing 'traditional' dances, Inganzo Ngari draws on the country's cultural past - which, importantly, is purged of ethnic and regional difference - to create an image of Rwanda that is at once modern and rooted in a particular understanding of the country's history.

Thus, rather than hinging on individual 'authenticity', becoming a 'superstar' in the Rwandan context hinges upon the ability to reproduce government ideology for the state with both bodies and words (so it can monitor these performances) and, given the heavily mediatized nature of the competition, for young people at home (so they in turn can 'play back' these performances for the state in their everyday lives). Following Wedeen's (1999) work on political spectacles, these performances are not about producing legitimacy, but rather about producing compliance or obedience. They ensure that Guma Guma participants act 'as if' they believe in the government's banyarwanda project, regardless of whether or not its narrative silences their own experiences and memories. As Wedeen has argued, such a 'politics of public dissimulation' is effective because it 'produces guidelines for acceptable speech and behavior' and 'clutters public space with monotonous slogans and empty gestures' (Wedeen 1999: 6).

I began to understand the performances required of Guma Guma contestants as 'playback' during a visit to two genocide memorials, Ntarama and Nyamata, in April 2012. During the short visits - both sites were visited on the same day - guides explained the significance of the memorials to the contestants while journalists filmed and took photographs. Both sites were Catholic churches that had

\footnotetext{
${ }^{13}$ I contribute here to work that investigates the ways in which post-genocide subjectivities are formed. Purdeková, for example, has argued that the RPF's various development initiatives, particularly the civic education programmes of ingando and itorero, aim to transform young people into 'ideal development subjects', who are defined by a number of characteristics including fluency in development discourses, 'combative zeal' and loyalty (Purdeková 2012: 195). Breed, on the other hand, explores how the 'new Rwandan subject' is being created through 'theatre, juridical systems and grassroots associations' (Breed 2014: 10).
} 
become massacre sites in 1994: at Ntarama, 5,000 people had been slaughtered; at Nyamata, 10,000. In many ways, the contestants were physically enacting the official 2012 genocide commemoration theme: 'Learning from history to shape a bright future' ('Twigire ku mateka twubaka ejo hazaza').

During these memorial visits, I was struck by the way in which photographers zoomed in on contestants' faces as they gazed at torn clothing, skulls and commemorative plaques. This close-up camerawork did not seem to be about getting closer to the 'authentic' self of a star (Holmes 2004: 161; Gamson 1994), but rather to ensure that contestants performed the 'right' kind of bodily postures - downcast eyes, lowered heads - and thus communicated the 'right' kind of emotions - solemnity, respect - for audiences who would later watch the show on television screens or see photographs on popular entertainment websites. Other affects - of fear at the bones and bloodied clothing, of disgust, of anger, of shame - that suggested 'unofficial' memories and personal histories seemed to be (tacitly) forbidden. Writing of Nyamata and other well-known memorials, Meierhenrich has argued that they 'service privileged memory, that is, memory that is officially sanctioned because it is in accordance with the postgenocidal raison d'état' (2011: 288). Indeed, as numerous scholars have pointed out, memory has become highly politicized in the post-genocide period as the 'official' narrative of the genocide constructs Tutsi as survivors and Hutu as perpetrators (Burnet 2009; Lemarchand 2009; Vidal 2004). Hutu killed during the genocide and those killed, both Hutu and Tutsi alike, by violence perpetrated by the RPF are erased from the national imagination (Burnet 2009: 95). In this sense, the cameras present during the Guma Guma memorial visits were not 'neutral' technologies that set out to capture 'truth' (Askew 2002b: 7), but rather technologies of surveillance that worked to ensure that contestants were seen to remember the past in the 'right' way.

Furthermore, 'playback' required certain kinds of public utterances. After the memorial visits, for example, artists riffed on the 'never again' theme. King James told a local journalist: 'As artists, it is our duty to sensitize and prevent such events to happen again in our country. We have to be part of our history' (Hope Magazine 2012). Similarly, when contestants were asked by local journalists what they would do with the money if they won - a popular question - artists inevitably said they would 'help' (gufasha) the community, usually framed in terms of 'the people' (abaturage) or 'the poor' (abakene), although often particular categories of people were singled out, such as widows (abapfakazi) or orphans (abafubyi).

These answers, however, were repeated so regularly that they became almost meaningless, as if they were playing on a constant 'playback' loop. During the last Guma Guma 2 press conference before the finale, a journalist friend went to interview the final two contestants, King James and Jay Polly, for his radio show. When I asked him afterwards what he had asked them, he told me, rolling his eyes: 'I asked how they were feeling. They were both confident. I asked what they would do with the money. They both said they would help people. But they always say that.' These statements about 'helping' the poor were rarely accompanied by concrete actions, but this did not mean that they were not productive (Austin 1962). Like the embodied performances discussed above, they produced a particular kind of post-genocide subject, one willing to be governed by the RPF, one ready to help 'rebuild' (kubaka) the nation. 
Although keeping a close eye on musicians and the popular media is understandable given the country's history, critics accuse the RPF of instrumentalizing the past to quash any views that diverge from the 'official' narrative (Freedom House 2012; Human Rights Watch 2014; Muganwa 2012; Waldorf 2007). Artists who have gone off script have been punished. Although I have already mentioned Rutabana, a more recent example is Kizito Mihigo, a well-known Catholic singer and peace and reconciliation activist who was sentenced to ten years in prison in February 2015 for 'planning to kill President Kagame and inciting hatred against the government' (BBC Africa 2015). Despite the charges against him, many believed that a controversial song Mihigo had released for the twentieth anniversary of the genocide, 'Igisobanuro cy'urupfu' ('The meaning of death'), had contributed to his downfall. In it Mihigo sings that those whose lives were 'brutally taken' in acts 'not qualified as genocide' equally deserve to be remembered. Such lyrics, which implicitly assert that slain Hutu should also be included in commemoration practices, contravene the official narrative. The singer's swift downfall can be read as a warning to other artists: performances straying beyond 'playback' would not be tolerated.

Despite the RPF's claims to build a 'new' Rwanda, its co-option of popular artists suggests continuities with the past. ${ }^{14}$ Just like igisope artists under Habyarimana, popular artists in the post-genocide period are required to "play back' government rhetoric to the state and the Rwandan public more widely through their bodies and words. Although igisope artists had sung the praises of the MRND, in the post-genocide era popular artists 'sensitize' young people on how to participate in the RPF's various programmes (umuganda, genocide commemoration) and to put aside any personal differences - ethnic, regional, familial, their status as returnee or umusope - and present themselves as 'Rwandan'. While the line separating popular culture from government propaganda has often been blurred in Rwanda, I suggest that it has become even more so in the post-genocide period due to the RPF's particular form of 'developmental patrimonialism' in which the ruling party owns or controls a number of 'private' enterprises (Booth and Golooba-Mutebi 2012). Given that Bralirwa, MTN and other media and telecommunications businesses in the country are owned in whole or in part by the RPF (Gökgür 2012), the division between 'official' and 'unofficial' cultural events has become increasingly difficult to discern.

\section{'Live' surprise, take 1: the stoning of Tom Close}

If the 'playback' performances required by Guma Guma were about creating governable post-genocide celebrity subjects, this was not how Rwandan audiences interpreted the competition. Performances, after all, are not 'the exclusive tool of power-holders' (Askew 2002a: 6; see also Willems 2015), but rather are actively

\footnotetext{
${ }^{14}$ As Desrosiers and Thomson (2011) have argued, there are clear continuities between the regimes of Habyarimana and Kagame, particularly regarding how both position themselves as 'benevolent leaders' capable of ushering in a 'new' Rwanda.
} 
interpreted by audiences. ${ }^{15}$ In her work on taarab, a popular music genre in Tanzania, Askew aptly demonstrates how, despite attempts by political parties to co-opt the genre for propaganda purposes, audience members, especially women, continue to interpret songs according to their own 'politics of the personal' and use taarab performance as a way to reconfigure social relations. Askew makes a wider point about politics and musical performance, arguing that, although 'performing the nation brings it into being' (2002a: 292), the nation brought forth is necessarily 'disjunctive, fragmented, and internally contradictory' (ibid.: 281). Following Askew, I examine in the next two sections the ways in which Guma Guma exposed the cracks within the RPF's banyarwanda project.

Let us consider, for example, the controversy surrounding the first winner of Guma Guma, Tom Close. In the 2011 finale at Amahoro stadium, it came down to two finalists: Tom Close and King James, both R\&B singers. When it was announced that Close had won, the crowd revolted. Fans - particularly of runner-up Jay Polly, a rapper who had narrowly missed a spot in the top two saw Close's win as evidence that the competition was rigged, and began throwing stones (gutera amabuye) at the stage. The emcee of the event, Lion Imanzi, 'was forced to beg for mercy from the mad crowds' (Munyaneza 2011). Unconvinced by the legitimacy of Close's win, fans and journalists alike later called on Bralirwa to improve the 'transparency' of the SMS voting system (ibid.).

The controversy surrounding Close's win revealed conflicting criteria for who truly deserved to be a 'superstar'. Close and Jay Polly cultivated very different public personas and attracted very different kinds of audiences. Close was often derided as the 'king' of playback and gushishura - a practice in which artists copied foreign songs and translated them into Kinyarwanda - while Jay Polly was revered for speaking the 'truth' of everyday life. Close's music addressed the joys and difficulties of love and relationships, and, as we saw, he had composed a song for Kagame's 2010 presidential campaign. Clean-shaven and neatly dressed, he was studying medicine at the National University of Butare, Rwanda's most prestigious tertiary institution. Reflecting his own status, his fans were mostly, though not exclusively, middle-class (female) students.

Jay Polly, on the other hand, fashioned himself in the subversive guise of global hip-hop. He was known by fans as the 'gospel gangster' and 'umwana w'umuhanda' - literally, 'a child of the street'. He was a founding member of the rap crew Tuff Gang, pioneers of 'old school' rap in the country who were beloved by fans - mostly young, male, and impoverished - for speaking the 'truth' (ukuri) about the hardships of post-genocide life. While he, too, performed at state events - a concert in honour of the RPF's twenty-fifth anniversary in December 2012, for example - his music often articulated a sense of defiant sorrow. Much in line with other work on hip-hop in East Africa (Eisenberg 2012; Kerr 2016; 2015; Perullo 2005; Weiss 2009), we can see Rwandan hip-hop as offering the opportunity for marginalized young people, particularly young men, to fashion alternative forms of selfhood. Here, this sense of self was built not on the ability to 'play back' government ideology, but rather on the ability

\footnotetext{
${ }^{15}$ Indeed, as Wedeen has argued, political spectacles 'reveal both the power and the limitations of the regime's project by announcing the gap between enforcing participation and commanding belief' (Wedeen 1999: 22).
} 
to survive and rise above hardships. As the chorus of Jay Polly's hit song 'Ndacyariho' ('I'm still alive') declares: 'I'm still alive and breathing ... You who made me feel sorrow/Didn't know I would rule music'. ${ }^{16}$

The controversy surrounding Close's win also evoked ethnicity in uneasy ways. While fans rarely told me that they preferred a certain artist based on his or her ethnic identity - this, after all, would contravene the banyarwanda project - they were aware of it. ${ }^{17}$ It was public knowledge that Close was Tutsi and had grown up in Uganda, and that his parents had been involved in the Liberation Struggle. Jay Polly, on the other hand, had been born and raised in the country and was perceived to be Hutu. Yet it would be a mistake to reduce Close's stoning to ethnic difference. This became clear to me during a conversation with Janvier, a Tutsi genocide survivor in his late twenties who was one of Jay Polly's most ardent fans. He explained his admiration for the rapper to me in this way:

Me, I don't love Jay Polly because he's a star. I love that the message we wanted is passing through him at this period ... [B]efore there was Riderman [a popular Tutsi rapper who was a returnee from Burundi] singing the thing called hip-hop ... People who have a family, who has life, who has somebody to support them and somebody to be there for them. You see? But also there was another group of people who sing, but who sleeps in the ghetto with other friends, who don't eat twice a day, sometime even once. These people had their way of seeing life, of seeing lyrics ...

Here, the 'we' Janvier emphasizes is not based on ethnic identity, but rather on socio-economic position and personal history (see also Thomson 2013: 184). Rwandans who were born and raised in the country, the so-called abasope described above, saw themselves and their experiences as vastly different from those of wealthier returnees, mostly Tutsi, who had returned to the country after the genocide. By documenting this painful 'ghetto' life, rappers such as Jay Polly validated it, and forged a hip-hop identity based not on ethnicity but rather on the mutual experience of poverty and sorrow. Close's Guma Guma win seemed to undermine the 'truth' of this message and suggested that impoverished young people of all ethnic groups had little say in the country's present or future.

\section{'Live' surprise, take 2: 'The North' (Majyaruguru) and the new akazu}

If the controversy surrounding Tom Close's win was the primary 'live' surprise of the first season of Guma Guma, a controversy over the rapper Young Grace's fan base was the 'live' surprise of the second. The incident revealed anxieties about Rwanda's north (Majyaruguru) in both the past and the present.

\footnotetext{
${ }^{16}$ The lyrics to the chorus are, in full: 'I'm still alive and breathing/Kept away for a long time/ But now I'm the corner stone/You who made me feel sorrow/Didn't know I would rule music' ('Ndacyariho ndahumekalNahejwe kuva keralAriko nakomeje imfurukalMwe mwanteye agahindalNtawari uziko naba kizigenza muri muzika').

${ }^{17}$ As Hilker $(2014 ; 2012 ; 2009)$ has observed, ethnic identity continues to be a salient category in young Rwandans' lives, shaping how they perceive themselves and others.
} 
During the second elimination round of Guma Guma 2, controversy erupted over emcee Imanzi's interview with Young Grace, an eighteen-year-old rapper from Gisenyi, a city in northern Rwanda bordering Goma, Democratic Republic of the Congo (DRC). In the format of the live shows, artists would perform individually and then Imanzi would ask them several questions. After Young Grace's performance, Imanzi questioned her about her supporters. Given Young Grace's home town, Imanzi jokingly asked her if her fans were only family members or those from the north (Majyaruguru). Yet since Rwanda's north has historically been considered a predominantly Hutu area, Imanzi was accused of 'regionalism'. Journalists and fans accused him of 'offending' (yabajije) Young Grace (Muhawe 2012). His questions were deemed 'inappropriate' (Kagire 2012) and there were rumours that he would be forced to resign. In the end, Imanzi publicly apologized to Young Grace (gusaba imbabazi) and continued as the competition's emcee (Muhawe 2012).

Although fandom, as we saw, was not necessarily linked to ethnic identity, the Young Grace incident revealed that it held a complex relationship with regional identity and history. Everyone I knew was convinced that Young Grace's supporters were mostly from the north - and, implicitly, Hutu - but to admit it so publicly undermined the very premise of the Guma Guma franchise (to find a Rwandan 'superstar') and the RPF's political project (to create a unified Rwanda and inclusive banyarwanda identity). It also hinted that historical anxieties about the north (Majyaruguru) as an independent site of power continue to inflect public discourse. During the eighteenth century, when the kingdom of Rwanda expanded outwards from Buganza, Hutu principalities in the north - but also in the south-west - remained 'defiant', and in some instances were incorporated into the Rwandan polity only in the twentieth century, with the help of European colonizers (Prunier 1995: 18-9; see also Des Forges 2011). ${ }^{18}$ After the RPF ended the genocide, the north-west, particularly the prefectures of Gisenyi and Ruhengeri, became a site of insurgency in 1997-98, when members of FAR (Forces armées rwandaises), the former national army, and the Interahamwe attempted to destabilize the RPF regime (Jackson 2004).

To many fans, the Young Grace incident demonstrated not only the enduring influence of northern identity, but also that the music industry more generally was governed by corruption (ruswa) and favouritism (ikimenyane). While artists such as Young Grace were accused of buying votes, other artists were accused of succeeding in the competition because of connections. ${ }^{19}$ Tellingly, rumours circulated that the music industry was controlled by an akazu (little house); this was the same word that had been used to describe the Hutu elite surrounding Habyarimana, made up in part by members of his wife's northern lineage, that had orchestrated the genocide. According to De Lame (2004), the term akazu

\footnotetext{
${ }^{18}$ Region was salient under the first two Hutu republics, with first president Grégoire Kayibanda privileging Hutu from his native region of Gitarama, and Habyarimana privileging Hutu from his native region of Gisenyi.

${ }^{19}$ Fans complained to me that King James's producer and manager worked for EAP during Guma Guma 2.
} 
indexes the relationship between secrecy and power that has characterized the Rwandan socio-political universe since the precolonial period..$^{20}$

Ironically, despite the RPF's claims to political transparency, we can trace similarities with a 'politics of illusion' that Apter (2005) has identified in post-oil boom Nigeria. Apter details how the promises of prosperity and modernity ushered in by the oil boom of the 1970s - epitomized by the 'spectacle' of Nigerian culture on display at FESTAC, an international festival of African culture - gave way to 'a social world not of objects and things but of smoke and mirrors, a business culture of worthless currency, false facades, and empty value forms' (Apter 2005: 235) when the oil (and political) economy of the country went bust in the 1990s. Although Apter writes of the spectacle and its ensuing evacuation as two distinct though interrelated historical moments - built on the shifting value of oil - in Rwanda we see the collapse of these moments into one. At the same time that Guma Guma offered the 'spectacle' of Rwandan identity, audience members expressed anxieties that it held only a tenuous relationship with the 'real', and that the social world around them was not what it seemed. Here, this sense of "nervousness' (Apter 2005) coincided not with the decline in oil revenues, as in Nigeria, but rather with contestations over 'official' and 'unofficial' truths in the post-genocide period. I explore these contestations below.

\section{'Playback' versus 'live' music: contestations over 'truth'}

I argued above that the performances demanded by Guma Guma contestants should be understood as 'playback', as they reproduce the state's attempt to create a unified banyarwanda identity. Yet, paradoxically, it was Guma Guma itself that brought the artificiality of playback to the audience's attention by requiring artists to perform 'live' during the final round of the competition.

The importance of live Guma Guma performances was articulated to me by Gaston Rurangwa, a member of the popular boy band Kigali Boys and a radio presenter. As he told me in an interview:

People didn't know that playback was spoiling the music. When it comes to Guma Guma, that's when people started hearing, 'Oh, these were the people who are singing good and they don't know how to sing!' Auto-Tunes, effects, the sounds, the vocals is good, but when it comes to the microphone, it's like a frog. [Chuckles.] That's when people started hating these guys, started realizing that these artists are lying to them. So that's how things are starting to change. That's how fans are starting to clamour, 'No, we don't want this!'

Indeed, after Guma Guma, radio presenters began vocally criticizing corruption in the music industry, and a new emphasis was placed on live performance. ${ }^{21}$

\footnotetext{
${ }^{20}$ The akazu under Habyarimana was not unique but in fact recalled the inner circle around King Musinga (1896-1931) that orchestrated his rise to power (De Lame 2004: 293; see also Des Forges 2011).

${ }^{21}$ One of the most vehement critics was a radio presenter named DJ Adams, often credited with first exposing the phenomenon of gushishura. On his popular radio programme, Adams would often play the two tracks - the foreign original and the gushishura copy - back to back so that
} 
It is worth stressing that this emphasis on 'live' differs dramatically from other musical contexts. Media scholars and ethnomusicologists have long argued that while 'live' is often defined against 'mediated' or 'mediatized' - with 'live' associated with authenticity and proximity, and 'mediated' with technological manipulation and artificiality - this distinction is not natural but culturally and historically determined, and highly dependent on genre (Auslander 2008; 1999; Firth 1986). In some cases, 'live' is a sonic characteristic to be achieved not in performance but in the studio, through specific technological manipulations (Porcello 2002). In other cases, live performance is seen as increasingly irrelevant. Shipley comments that live performance in Ghanaian hiplife 'is less central to the music's social relevance than its urban and technological circulations' (2009: 660).

Why, then, the enduring importance of 'live' performance in Rwanda? To explore this question, I turn to Meintjes' (2003) ethnography of a South African recording studio. Meintjes argues that 'liveness' takes on particular resonances within an African context, and that 'live' is constituted in relation to the global music industry, and particularly to the genre of world music. South African musicians and producers who aspire to global success must cultivate 'liveness' in their recordings, yet this very idea of 'liveness' depends upon essentialized notions of Africanness in which Africans are assumed to be 'natural' musicians - 'To sound authentically African is to sound live' (Meintjes 2003: 112). And if 'liveness' provides privileged access to world music markets for the mbaqanga musicians and producers Meintjes describes, it also calls attention to the fact that other musical styles lack these qualities. While sound and tuning are essential features of music that strives to reach the global, music that does not share these qualities is understood as being destined for the less lucrative - and, notably, black - domestic market (Meintjes 2003: 244-6). Through this twotiered hierarchy of sound, social, economic and racial difference is constituted. Larkin has made a similar point about piracy in Nigeria, arguing that ' $[\mathrm{w}] \mathrm{hile}$ media infrastructure creates the reality of being ever more connected to a globalized world, it does so by emphasizing Nigerians' marginalization at the same time' (Larkin 2004: 308). Thus, while 'live' may index aspiration and the desire to access the global and modern, the 'out-of-tune' may index ongoing processes of exclusion.

Applying these insights to Rwanda, if live is the medium through which Rwandan musicians make claims to global musical success during Guma Guma, when they sing 'out of tune' they reveal the failure of this project. In Western musical reality shows, after all, the winner must be able to perform live, and the fact that local musicians could not do so only served to reinforce young Rwandans' sense of marginalization and experiences of being 'stuck', as Sommers (2012) has argued. Guma Guma can be seen, in this sense, as a site not of global aspiration, but of failed 'bluff'. In his work on youth culture in Côte d'Ivoire, Newell writes that the point of the 'bluff' - which involves performing affluence through consumer goods - is not about young people trying to 'fool' others, but rather about 'convinc[ing] them that they knew how to be rich, how to embody the identity and lifestyle of those they aspired to become' (Newell 2012:

audience members could hear for themselves and decide whether or not local artists had been 'stealing' songs from others. 
144). The failure of Guma Guma artists to perform live revealed that they in fact did not know how to be 'superstars' and could not embody the successful transnational lifestyle to which audience members aspired. It also revealed the underdevelopment of the local music industry; despite the spectacle of Guma Guma, it did not and could not produce internationally competitive artists.

How, then, might we understand the relationship between 'liveness' and 'truth'? As Rurangwa's comments elucidated, artists who could not perform live were accused of lying (kubesha) to the public, and one Kinyarwanda translation of live music was 'umuziki w'ukuri' - literally, 'the music of truth'. While these demands for truth on one level expressed failed global aspiration, as I argued above, they also hinted at the unstable nature of 'truth' in the post-genocide period more broadly (Fujii 2010; Ingelaere 2009; Reyntjens 2015). Ingelaere (2009) has argued that conflicting 'regimes of truth' (Foucault 1980: 131) operate in Rwanda today, especially after the implementation of gacaca, "traditional' community courts set up in 2001 to try cases of genocide. Citing Ferme (2001), he suggests that " $\mathrm{f}] \mathrm{facts}$ and perceptions, claims and convictions seek refuge in the "underneath of things", a second world constituted in relation to the first world of social reality and rooted in the collective social imaginary' (Ingelaere 2009: 524).

Ingelaere argues that rumours offer a glimpse into this imaginary: I suggest that Guma Guma does so in a similar vein, and that the category of 'liveness' mediates between the two worlds he identifies. Much as Pype has argued that Pentecostal teleserials in Kinshasa 'mediate between various religious worlds' (2012: 14), notably the demonic and the divine, so too does Guma Guma mediate between various truth regimes, transmitting both messages that affirm the RPF's particular 'vision' for the country and those that undermine it. Guma Guma became so popular, I suggest, because of this ambiguity: at the same time as it mandated the playing back of government ideology and 'truth', it created a space for the possibility of other 'live' surprises, and allowed debates about Rwandan identity and 'truth', silenced elsewhere, to take place. More to the point, it hints at a disjuncture between the 'playback' performances of a unified Rwandan identity that the RPF demands and the 'live' experiences (and memories) of marginalization and hardship that young people in the country continue to face.

The uproar over a controversial BBC television documentary that challenged the RPF's official narrative about the genocide - and resulted in the indefinite ban of the BBC Kinyarwanda service - only made clear how contested 'truth' is in Rwanda and how pervasive 'playback' performances have become. ${ }^{22}$ Within such a highly controlled media context, audience demands for 'live' suggest alternative ways of relating both to the state and to others. These demands were quite literally demands for 'truth' (ukuri): for artists to strip away technological mediation (Auto-Tune, for one) and powerful connections

\footnotetext{
${ }^{22}$ The documentary 'Rwanda's untold story', which was aired on 1 October 2014, suggested that the RPF was responsible for massacres of Hutu civilians in Rwanda and the DRC, that 'death squads' killed the regime's enemies abroad, and that more Hutu than Tutsi were killed in 1994 (Reyntjens 2015: 637-8). As a result, Kagame accused the BBC of 'genocide denial' and an official commission of inquiry was launched, which ultimately concluded that the documentary minimized and denied the genocide (Reyntjens 2015: 639, 645).
} 
(within the Guma Guma organization and beyond) and to prove themselves truly deserving of recognition and success. While the parameters of the 'truth' they sought may seem modest, they hinted at other forms the nation may take and other kinds of identities and positions young people may adopt within it.

\section{Conclusion}

In this article, I have attempted to consider local understandings of playback and live seriously. I have argued that playback can be understood as a wider metaphor for state-society relationships as young people are required to reproduce, through both bodies and words, a 'new' de-ethnicized Rwandan identity. Against work that celebrates the 'moments of freedom' (Fabian 1998) inherent within popular culture, I argue that popular artists in Rwanda are required to perform compliance and that the RPF's involvement in 'private' enterprises challenges any easy distinction between 'official' and 'unofficial' media spaces. In other contexts of 'developmental patrimonialism', careful attention must be paid to how, where, and by whom the line between the two is drawn.

Yet Guma Guma made it clear that playback can only be constituted in relation to the live. And here live performance held out alternative possibilities. Instead of merely repeating playback performances, Guma Guma offered the possibility of transforming the self, like Jay Polly, from a 'child of the street' to a 'superstar' with powerful international connections. Artists who could not perform live symbolized young people's sense of failed aspiration, as, despite the 'promises of development, social mobility, and dignity' (Pells et al. 2014: 304) the RPF offers young people, they continue to experience hardship, poverty and exclusion in their everyday lives. While the RPF positions itself as the sole purveyor of 'truth', Guma Guma revealed that other truths - about the kind of nation young Rwandans wanted to inhabit, and the kinds of persons deserving of recognition and success - were being articulated, contested and refashioned within popular culture. In this sense, the category of 'liveness' became a form of mediation: it mediated between various regimes of truth and ultimately revealed the ambiguity and uncertainty at the heart of the RPF's banyarwanda project. While much recent work on media and mediation has helpfully broken down the distinction between the live and the mediated, I suggest that it may be worth exploring the ways in which this boundary continues to do cultural and political work. In states that foreground technological advancement as the key to development and modernity, 'liveness' might prove to be a salient form of critique and, indeed, mediation between various kinds of 'truths'.

\section{Acknowledgements}

This research was funded by the Clarendon-St Hugh's College Louey Scholarship, the Canadian Centennial Scholarship Fund (CCSF), and the Godfrey Lienhardt Memorial Fund Travel Grant. I thank Harri Englund, Miriam Driessen, Carine Plancke and Christina Woolner for helpful comments on various versions of this article, as well as this journal's two anonymous reviewers. An earlier version of this paper was presented at 
SOAS's Music Department's public seminar, and I am grateful in particular for the feedback of Angela Impey and Hélène Neveu Kringelbach.

\section{References}

Apter, A. (2005) The Pan-African Nation: oil and the spectacle of culture in Nigeria. Chicago IL: University of Chicago Press.

Askew, K. (2002a) Performing the Nation: Swahili music and cultural politics in Tanzania. Chicago IL: University of Chicago Press.

Askew, K. (2002b) 'Introduction' in R. Wilk and K. Askew (eds), The Anthropology of Media: a reader. Malden MA: Blackwell Publishers.

Auslander, P. (1999) Liveness: performances in a mediatized culture. London: Routledge.

Auslander, P. (2008) 'Live and technologically mediated performance' in T. Davis (ed.), The Cambridge Companion to Performance Studies. Cambridge: Cambridge University Press.

Austin, J. L. (1962) How to Do Things with Words. Oxford: Clarendon Press.

Barber, K. (1987) 'Popular arts in Africa', African Studies Review 30 (3): 1-78.

Barber, K. (ed.) (1997) Readings in African Popular Culture. Bloomington IN: International African Institute in association with Indiana University Press.

Barber, K. (2007) The Anthropology of Texts, Persons and Publics. Cambridge: Cambridge University Press.

BBC Africa (2015) 'Rwanda singer Kizito Mihigo planned to kill Paul Kagame', BBC Africa, 27 February <http://www.bbc.co.uk/news/world-africa-31656169>, accessed 27 February 2015.

Booth, D. and F. Golooba-Mutebi (2012) 'Developmental patrimonialism?: The case of Rwanda', African Affairs 111 (444): 379-403.

Breed, A. (2008) 'Performing the nation: theatre in post-genocide Rwanda', The Drama Review 52 (1): 32-50.

Breed, A. (2014) Performing the Nation: genocide, justice, reconciliation. London: Seagull Books.

Buckley-Zistel, S. (2006) 'Remembering to forget: chosen amnesia as a strategy for local coexistence in post-genocide Rwanda', Africa 76 (2): 131-50.

Burnet, J. (2009) 'Whose genocide? Whose truth? Representations of victim and perpetrator in Rwanda' in A. L. Hinton and K. O'Neill (eds), Genocide: truth, memory, and representation. Durham NC: Duke University Press.

Burnet, J. (2012) Genocide Lives in Us: women, memory, and silence in Rwanda. Madison WI: University of Wisconsin Press.

Chrétien, J. P. (1995) Rwanda: les médias du génocide. Paris: Karthala.

Coupez, A. and T. Kamanzi (1962) Récits historiques Rwanda: dans la version de C. Gakanbiisha. Tervuren: Musée royal de l'Afrique centrale.

Coutas, P. (2006) 'Fame, fortune, fantasi: Indonesian Idol and the new celebrity', Asian Journal of Communication 16 (4): 371-92.

Craig, D. and N. Mkhize (2006) 'Vocal killers, silent killers: popular media, genocide, and the call for benevolent censorship in Rwanda' in M. Drewett and M. Cloonan (eds), Popular Music Censorship in Africa. Aldershot: Ashgate.

Dauge-Roth, A. (2010) Writing and Filming the Genocide of the Tutsis in Rwanda: dismembering and remembering traumatic history. Lanham MD: Lexington Books. 
De Lame, D. (2004) 'Mighty secrets, public commensality, and the crisis of transparency: Rwanda through the looking glass', Canadian Journal of African Studies 38 (2): 279-317.

Des Forges, A. (2007) 'Call to genocide: radio in Rwanda, 1994' in A. Thompson (ed.), The Media and the Rwanda Genocide. London: Pluto Press.

Des Forges, A. (2011) Defeat Is the Only Bad News: Rwanda under Musinga, 1896-1931. Edited by D. Newbury. Madison WI: University of Wisconsin Press.

Desrosiers, M. E. and S. Thomson (2011) 'Rhetorical legacies of leadership: projections of "benevolent leadership" in pre- and post-genocide Rwanda', Journal of Modern African Studies 49 (3): 429-53.

Dyer, R. (1998) Stars. London: BFI.

Eisenberg, A. (2012) 'Hip-hop and cultural citizenship on Kenya's "Swahili Coast", Africa: 82 (4): 556-78.

Fabian, J. (1998) Moments of Freedom: anthropology and popular culture. Charlottesville VA: University Press of Virginia.

Ferme, M. (2001) The Underneath of Things: violence, history, and the everyday in Sierra Leone. Berkeley CA: University of California Press.

Firth, S. (1986) 'Art versus technology: the strange case of popular music', Media, Culture, Society 8 (3): 263-79.

Foucault, M. (1980) Power/Knowledge: selected interviews and other writings, 1972-1977. Brighton: Harvester.

Freedom House (2012) 'Rwanda: Freedom in the World'. Freedom House <http:/l www.freedomhouse.org/report/freedom-world/2012/rwanda\#.VBGSdld218E >, accessed 11 September 2014.

Frère, M. S. (2009) 'After the hate media: regulation in the DRC, Burundi and Rwanda', Global Media and Communication 5 (3): 327-52.

Fujii, L. A. (2010) 'Shades of truth and lies: interpreting testimonies of war and violence', Journal of Peace Research 47 (2): 231-41.

Gamson, J. (1994) Claims to Fame: celebrity in contemporary America. Berkeley CA: University of California Press.

Gansemans, J. (1988) Les instruments de musique du Rwanda : étude ethnomusicologique. Louvain: Leuven University Press.

Gökgür, N. (2012) 'Rwanda's ruling party-owned enterprises: do they enhance or impede development?' IOB Discussion Paper. Antwerp: University of Antwerp <http://EconPapers.repec.org/RePEc:iob:dpaper:2012003>, accessed 18 April 2016.

Grant, A. M. (2015) 'Quiet insecurity and quiet agency in post-genocide Rwanda', Etnofoor 27 (2): 15-36.

Hilker, L. (2009) 'Everyday ethnicities: identity and reconciliation among Rwandan youth', Journal of Genocide Research 11 (1): 81-100.

Hilker, L. (2012) 'Rwanda's "Hutsi": intersections of ethnicity and violence in the lives of youth of "mixed" heritage', Identities 19 (2): 229-47.

Hilker, L. (2014) 'Navigating adolescence and young adulthood in Rwanda during and after genocide: intersections of ethnicity, gender and age', Children's Geographies 12 (3): 354-68.

Holmes, S. (2004) “"Reality goes pop!”: reality TV, popular music, and narratives of stardom in Pop Idol', Television \& New Media 5 (2): 147-72. 
Hope Magazine (2012) 'Guma Guma artists on a genocide memorial tour', Hope Magazine, 11 April <http://www.hope-mag.com/index.php?com=news \&option=read\&ca $=1 \& a=101>$, accessed 17 September 2015.

Human Rights Watch (2014) 'World report 2014: Rwanda'. Human Rights Watch $<$ http://www.hrw.org/world-report/2014/country-chapters/rwanda>, accessed 22 January 2014.

Ingelaere, B. (2009) "“Does the truth pass across the fire without burning?": Locating the short circuit in Rwanda's gacaca courts', Journal of Modern African Studies 47 (4): 507-28.

Jackson, P. (2004) 'Legacy of bitterness: insurgency in North West Rwanda', Small Wars \& Insurgencies 15 (1): 19-37.

Kagame, A. (1951) La poésie dynastique au Rwanda. Brussels: Institut royal colonial belge.

Kagire, E. (2012) 'Young Grace, Knowless out of Guma Guma Superstar show', The East African, 20 July <http://www.theeastafrican.co.ke/Rwanda/Lifestyle/ Young-Grace-Knowless-out-of-Guma-Guma-superstar-show-/-/1433242/1459036/-/ item/0/-/jhhbaaz/-/index.html>, accessed 27 May 2014.

Kagire, L. (2013) 'In remembrance of musicians killed during the genocide', The New Times, 12 April <http://www.newtimes.co.rw/section/article/2013-04-12/ 64784/>, accessed 11 October 2016.

Kagire, L. (2015) 'Understanding the role of music in the struggle for liberation', The New Times, 4 July <http://www.newtimes.co.rw/section/article/2015-07-04/ 190310/>, accessed 11 October 2016.

Kerr, D. (2015) "Underground" rap performance, informality and cultural production in Dar es Salaam', Journal of African Media Studies 7 (1): 69-85.

Kerr, D. (2016) 'From the margins to the mainstream: making and remaking an alternative music economy in Dar es Salaam', Journal of African Cultural Studies 7: 1-14.

Larkin, B. (2004) 'Degraded images, distorted sounds: Nigerian video and the infrastructure of piracy', Public Culture 16 (2): 289-314.

Lemarchand, R. (2009) 'The politics of memory in post-genocide Rwanda' in P. Clark and Z. Kaufman (eds), After Genocide: transitional justice, post-conflict reconstruction and reconciliation in Rwanda and beyond. New York NY: Columbia University Press.

Mazzarella, W. (2004) 'Culture, globalization, mediation', Annual Review of Anthropology 33: 345-67.

McCoy, J. (2013) 'Mbwirabumva ("I speak to those who understand"): three songs by Simon Bikindi and the war and genocide in Rwanda'. PhD thesis, Florida State University.

McNeill, F. (2011) AIDS, Politics, and Music in South Africa. Cambridge: Cambridge University Press.

Meierhenrich, J. (2011) 'Topographies of remembering and forgetting: the transformation of lieux de mémoire in Rwanda' in S. Straus and L. Waldorf (eds), Remaking Rwanda: state building and human rights after mass atrocity. Madison WI: University of Wisconsin Press.

Meintjes, L. (2003) Sound of Africa!: Making music Zulu in a South African studio. Durham NC: Duke University Press.

Meizel, K. (2011) Idolized: music, media, and identity in American Idol. Bloomington IN: Indiana University Press. 
Muganwa, G. (2012) 'Rwanda media sustainability index 2012'. IREX<https:// www.irex.org/sites/default/files/pdf/media-sustainability-index-africa-2012-rwanda. pdf $>$, accessed 11 October 2016.

Muhawe, A. (2012) 'Lion Imanzi yeguye muri PGGSS II, anasaba imbabazi ku byo yabajije Young Grace', Igihe, 10 July < http:/www.igihe.com/coverages/ primus-guma-guma-superstar-ii/amakuru-1291/lion-imanzi-yeguye-muri-pggssii-anasaba-imbabazi-ku-byo-yabajije-young-grace>, accessed 14 November 2014.

Munyaneza, E. (2011) 'King James and Tom Close await final "Guma Guma" ruling', The New Times, 6 August <http://www.newtimes.co.rw/section/article/ 2011-08-06/84616/>, accessed 11 October 2016.

Newell, S. (2012) The Modernity Bluff: crime, consumption, and citizenship in Côte d'Ivoire. Chicago IL: University of Chicago Press.

Nkulikiyinka, J. B. (2002) Introduction à La Danse Rwandaise Traditionnelle. Tervuren: Musée royal de l'Afrique centrale.

Pells, K., K. Pontalti and T. Williams (2014) 'Promising developments?: Children, youth and post-genocide reconstruction under the Rwandan Patriotic Front (RPF)', Journal of Eastern African Studies 8 (2): 294-310.

Perullo, A. (2005) 'Hooligans and heroes: youth identity and hip-hop in Dar es Salaam, Tanzania', Africa Today 51 (4): 75-101.

Plancke, C. (2013) 'Danser pour donner: entretien avec Nido Uwera, chorégraphe rwandaise et directrice artistique de la troupe Mpore', Recherches en Danse $<$ http://danse.revues.org/479>, accessed 7 April 2016.

Plancke, C. (2015) 'Donner corps au "Nouveau Rwanda": danse et reconstruction post-génocidaire', Cahiers d'Études Africaines 4 (220): 711-37.

Porcello, T. (2002) 'Music mediated as live in Austin: sound, technology, and recording practice', City \& Society 14 (1): 69-86.

Prunier, G. (1995) The Rwanda Crisis 1959-1994: history of a genocide. London: Hurst.

Punathambekar, Z. (2011) 'Reality television and the making of mobile publics: the case of Indian Idol' in M. Kraidy and K. Sender (eds), The Politics of Reality Television: global perspectives. London: Routledge.

Purdeková, A. (2012) 'Civic education and social transformation in post-genocide Rwanda: forging the perfect development subjects' in M. Campioni and P. Noack (eds), Rwanda Fast Forward: social, economic, military and reconciliation prospects. Basingstoke: Palgrave Macmillan.

Pype, K. (2009) 'Media celebrity, charisma and morality in post-Mobutu Kinshasa', Journal of Southern African Studies 35 (3): 541-55.

Pype, K. (2012) The Making of the Pentecostal Melodrama: religion, media and gender in Kinshasa. New York NY: Berghahn Books.

Reyntjens, F. (2013) Political Governance in Post-genocide Rwanda. Cambridge: Cambridge University Press.

Reyntjens, F. (2015) 'The struggle over truth: Rwanda and the BBC', African Affairs 114 (457): 637-48.

Schumann, A. (2012) 'A generation of orphans: the socio-economic crisis in Côte d'Ivoire as seen through popular music', Africa 82 (4): 535-55.

Schumann, A (2013) 'Songs of a new era: popular music and political expression in the Ivorian crisis', African Affairs 112 (448): 440-59. 
Shipley, J. W. (2009) 'Aesthetic of the entrepreneur: Afro-cosmopolitan rap and moral circulation in Accra, Ghana', Anthropological Quarterly 82 (3): 631-68.

Shipley, J. W. (2013) Living the Hiplife: celebrity and entrepreneurship in Ghanaian popular music. Durham NC: Duke University Press.

Sommers, M. (2012) Stuck: Rwandan youth and the struggle for adulthood. Athens GA: University of Georgia Press.

Straus, S. (2012) 'What is the relationship between hate radio and violence?: Rethinking Rwanda's "Radio Machete" in L. Gunner, D. Ligaga, and D. Moyo (eds), Radio in Africa: publics, cultures, communities. Oxford: James Currey.

Straus, S. and L. Waldorf (2011) 'Introduction: seeing like a post-conflict state' in S. Straus and L. Waldorf (eds), Remaking Rwanda: state building and human rights after mass atrocity. Madison WI: University of Wisconsin Press.

Swanson, B. (2014) 'The voice of Rwanda: an ethnomusicological biography of Jean-Paul Samputu'. PhD thesis, University of Maryland.

Taylor, C. (1999) Sacrifice as Terror: the Rwandan genocide of 1994. Oxford: Berg. Thompson, A. (ed.) (2007) The Media and the Rwanda Genocide. London: Pluto Press.

Thomson, S. (2013) Whispering Truth to Power: everyday resistance to reconciliation in postgenocide Rwanda. Madison WI: University of Wisconsin Press.

Tomás, A. (2014) 'Becoming famous: kuduro, politics and the performance of social visibility’, Critical Interventions 8 (2): 261-75.

UNMICT (2003) 'Three media leaders convicted for genocide'. Press release. United Nations Mechanism for International Criminal Tribunals (UNMICT),

3 December <http://unictr.unmict.org/en/news/three-media-leaders-convictedgenocide>, accessed 6 April 2016.

Vansina, J. (2004) Antecedents to Modern Rwanda: the Nyiginya Kingdom. Oxford: James Currey.

Vidal, C. (2004) 'La commémoration du génocide au Rwanda: violence symbolique, mémorisation forcée et histoire officielle', Cahiers d'Études Africaines 44 (175): 575-92.

Vokes, R. (2007) 'Charisma, creativity, and cosmopolitanism: a perspective on the power of the new radio broadcasting in Uganda and Rwanda', Journal of the Royal Anthropological Institute 13 (4): 805-24.

Waldorf, L. (2007) 'Censorship and propaganda in post-genocide Rwanda' in A. Thompson (ed.), The Media and the Rwanda Genocide. London: Pluto Press.

Wedeen, L. (1999) Ambiguities of Domination: politics, rhetoric, and symbols in contemporary Syria. Chicago IL: University of Chicago Press.

Weiss, B. (2009) Street Dreams and Hip Hop Barbershops: global fantasy in urban Tanzania. Bloomington IN: Indiana University Press.

Willems, W. (2015) 'Risky dialogues: the performative state and the nature of power in a postcolony', Journal of African Cultural Studies 27 (3): 356-69.

\begin{abstract}
This article considers the reconstruction of Rwanda's post-genocide music industry through the national music competition, Primus Guma Guma Super Star. It explores local ideas about 'playback' and 'live' music, and argues that these
\end{abstract}


two performative categories can be understood as wider metaphors for the relationship between the Rwandan state and its citizens, particularly Rwandan youth. On the one hand, Guma Guma aims to create the ideal post-genocide celebrity subject who will 'play back' a unified, de-ethnicized Rwandan identity with body and words. On the other, during the first two seasons of the competition, audiences demanded 'live' performance and Guma Guma prompted heated debate about 'taboo' topics, revealing enduring differences along socio-economic, ethnic and regional lines. Rather than affirm an inclusive Rwandan identity, Guma Guma hinted at its fragility and underscored the multiple and conflicting ways in which young people identify themselves and evaluate 'truth' in the post-genocide era. The article contributes not only to literature on popular culture in Africa, but also to studies that focus on mediation and changes in recording technology. Although scholars have quite rightly attempted to dissolve the boundary between the live and the mediated, I suggest that the boundary continues to do cultural and political work, particularly in developmental states.

\section{Résumé}

Cet article examine la reconstruction de l'industrie musicale au Rwanda post-génocide à travers le concours national de musique intitulé Primus Guma Guma Super Star. Il explore les idées locales concernant la musique en « playback » et en " direct », et soutient que l'on peut comprendre ces deux catégories de prestation comme des métaphores plus larges de la relation entre l'État rwandais et ses citoyens, et notamment les jeunes. D'un côté, Guma Guma vise à créer l'objet de célébrité post-génocide idéal qui interprétera en playback, par le corps et les mots, une identité rwandaise unifiée désethnicisée. De l'autre, au cours des deux premières saisons du concours, le public a réclamé des interprétations en direct et Guma Guma a déclenché des débats passionnés sur des sujets " tabous " révélant des différences persistantes sur des lignes socioéconomiques, ethniques et régionales. Plutôt que d'affirmer une identité rwandaise inclusive, Guma Guma a fait allusion à sa fragilité et souligné les manières multiples et divergentes dont les jeunes s'identifient et évaluent la "vérité » dans l'ère post-génocide. L'article contribue non seulement à la littérature sur la culture populaire en Afrique, mais aussi aux études sur la médiation et l'évolution des technologies d'enregistrement. Bien que les chercheurs aient tenté, à juste titre, de dissoudre la frontière entre le direct et la médiation, l'auteur suggère que la frontière poursuit son œuvre culturelle et politique, notamment dans les états de développement. 